\title{
BLOOD ENZYMATIC ACTIVITY IN SAANEN GOATS DURING DIFFERENT PERIODS OF THE REPRODUCTIVE CYCLE AND THEIR ASSOCIATION WITH THE COMPLETION OF PREGNANCY
}

\author{
V.B. LEIBOVA ${ }^{1}$, I.Sh. SHAPIEV ${ }^{1}$, I.Yu. LEBEDEVA ${ }^{2}$
}

\begin{abstract}
${ }^{1}$ All-Russian Research Institute of Genetics and Breeding of Farm Animals, Federal Agency of Scientific Organizations, 55a, Moskovskoe sh., St. Petersburg_Pushkin, 196601 Russia, e-mail leib1406@yandex.ru, shapievism@bk.ru; ${ }^{2}$ L.K. Ernst All-Russian Research Institute of Animal Husbandry, Federal Agency of Scientific Organizations, pos. Dubrovitsy, Podol'sk Region, Moscow Province, 142132 Russia, e-mail irledv@mail.ru Received August 19, 2015
\end{abstract}

\section{Abstract}

Metabolic processes in milk-producing cows are substantially modified that is the main reason of different abnormalities in the reproductive function. At the same time the pattern of metabolic changes and its influence on the reproductive capacity in high-producing dairy goats (Capra hircus) are yet unknown. The aim of the present work was to study the activity of metabolic enzymes in the blood of Saanen goats depending on the period of the reproductive cycle and the competence for pregnancy maintenance. We analyzed for the first time alterations in the serum activity of enzymes, regulating the intensity of protein-carbohydrate and energy metabolism including integration of metabolic processes, at different stages of goat gestation as well as prior to the mating period in animals with the negative outcome of the subsequent pregnancy. The enzyme status of animals was assessed during the pre-mating period, the first half of pregnancy (1.5-2.5 months), and the second half of pregnancy (3.5-4.0 months). Goats were divided into two groups with the completed reproductive cycle (the birth of viable offspring, $n=15$ ) and with the interrupted reproductive cycle (abortions in the second half of pregnancy, $n=6$ ). Samples of blood serum were tested to determine concentrations of total protein and activities of several enzymes: aspartate aminotransferase (AST, EC 2.6.1.1), alanine aminotransferase (ALT, EC 2.6.1.2), gamma glutamyltransferase (GGT, EC 2.3.2.2), creatine phosphokinase (CPK, EC 2.7.3.2), alkaline phosphatase (ALP, EC 3.1.3.1), lactate dehydrogenase (LDH, EC 1.1.1.27), and alpha hydroxybutyrate dehydrogenase (isoenzymes of LDH: LDH-1 and LDH-2). In goats with the completed reproductive cycle, the blood activity of AST in the second half of pregnancy was found to be 1.2 times lower $(\mathrm{p}<0.05)$ than during the pre-mating period or the first half of pregnancy. The activity of ALT in the blood serum of the animals increased 1.3 times $(\mathrm{p}<0.01)$ by $1.5-2.5$ months of pregnancy as compared with the pre-mating period and then decreased 1.9 times $(\mathrm{p}<0.001)$ by 3.5-4.0 months of pregnancy. Furthermore, there was a decline in the blood activities of GGT (1.3 times, $\mathrm{p}<0.05)$, CPK $(1.9$ times, $\mathrm{p}<0.01)$, and isoenzymes LDH-1 and LDH-2 $(1.3$ times, $\mathrm{p}<0.05)$ and a rise in the activity of ALP $(1.4$ times, $\mathrm{p}<0.05)$ between the first and the second half of pregnancy. During the pre-mating period, a lower activity of ALT and GGT was revealed in goats with the interrupted reproductive cycle as compared with animals retained pregnancy (14.4 \pm 2.9 vs. $20.1 \pm 0.7 \mathrm{U} / 1, \mathrm{p}<0.05$ and $43.8 \pm 2.4$ vs. $54.7 \pm 4.2 \mathrm{U} / 1, \mathrm{p}<0.05$, respectively). The results of this research suggest a reduction in the intensity of some metabolic processes in the goats by the fourth month of pregnancy to maintain increased fetus demands. Analysis of the findings also indicates that the activity of enzymes, regulating the coupling of protein and carbohydrate metabolism, in the blood of goats during the pre-mating period may be related to their subsequent capacity for fetus bearing.

Keywords: goat, saanen breed, pregnancy, metabolism, blood enzymatic activity, transferases

Currently, development of dairy goat breeding in both Russian Federation and foreign economically developed countries is aimed at the creation of large farms of industrial type [1]. At the same time, herd formation at large goat breeding farms is widely practiced in Russia as a result of the purchase of Saanen goats belonging one of the most highly productive breeds in the world [2]. Improvement of milk production is known to potentially violate a number of physiological functions, including reproduction, which is primarily due to meta- 
bolic modifications [3-6]. However, the pattern of metabolic changes and its effects on the reproductive capacity in dairy goats are yet unknown. Attempts have been made to define a metabolism-reproduction association in dairy goats. Thus, blood levels of certain metabolites and metabolic hormones have been studied during postpartum period and depending on goat gestation, gestation toxemia, and the number of lambings [7-10]. In addition, a comparative analysis of metabolic enzyme activity was performed in meat and dairy breeds with the different numbers of kids in the litter [11]. However, the available data do not allow to conclude on the association between metabolic types and the presence of reproductive disorders in dairy goats.

Earlier, we have studied biochemical blood parameters and metabolic interrelations in high yielding cows at different physiological periods and in connection with the service period [12-15]. In particular, we have found that under similar feeding and housing conditions, animals have varying ability to adapt to the metabolic imbalance. In the dry period and at the end of milking period, metabolism was characterized by an increased blood alanine aminotransferase activity (ALT, EC 2.6.1.2) in the cows of higher reproductive potential. Considering the role of ALT in the glucose-alanine cycle, the results indicated the involvement of protein and carbohydrate metabolism in maintaining cows' reproductive capacity in the critical physiological periods.

In dairy goats, reproduction intensity was largely determined by the capability to maintain the pregnancy $[16,17]$. However, infections of various etiology are not the only factor resulting in abortion as they were revealed in less than $40 \%$ of abortion [17-19]. The causes of the above pathology have not been determined almost in the half of examined animals. This suggests that a change in the nature or the intensity of metabolism may be one of the reasons for adverse pregnancy outcomes in high yielding goats. Indeed, one of the actual problems of high-yield dairy cattle breeding is gestational toxicosis, which is manifested in the violation of the immune, endocrine, anti-oxidant, and metabolic status of maternal organism [20, 21]. The failure of the mother's adaptive systems to provide the fetus requirements results in various negative consequences, including abortion, premature birth and reduced viability of offspring.

For the first time, we analyzed the alterations in the serum activity of enzymes which regulate the intensity of protein-carbohydrate and energy metabolism including integration of metabolic processes, at different stages of goat gestation and prior to the mating period in the animals with negative outcomes of subsequent pregnancies.

Our purpose was to study the blood metabolic enzymes' activity in the of Saanen goats depending on the period of reproductive cycle and the competence for pregnancy maintenance.

Technique. Studies were performed in the Prinevskoe JSC stud farm (Leningrad region) in 2010-2011. Saanen goats (Capra hircus) Saanen $(n=21)$ aged 3.5 years with an average annual milk productivity of $690-750 \mathrm{~kg}$ were the examined. Animal diet complied with the zootechnical standards accepted at the stud farm.

Biochemical parameters were assessed during the reproductive cycle: prior to the mating season (10 days before thee male goat mating), in the first (1.5-2.5 months) and second (3.5-4.0 months) halves of gestation which coincided with the dry period. Blood was sampled by jugular vein puncture in 3-4 hours after feeding. Based on pregnancy outcomes, goats were divided into 2 groups: I - with the completed reproductive cycle (birth of viable offspring, $n=15$ ), II - with interrupted reproductive cycle (abortions in the second half of gestation, $n=6$ ). Blood biochemistry parameters were not studied in 
3.5-4.0 months (second half of gestation) in group II animals because of interrupted pregnancies.

Blood serum samples were tested for total protein and activities of several enzymes: aspartate aminotransferase (AST, EC 2.6.1.1), alanine aminotransferase (ALT, EC 2.6.1.2 ), $\gamma$-glutamyltransferase (GGT, EC 2.3.2.2), creatine phosphokinase (CPK, EC 2.7.3.2), alkaline phosphatase (ALP, EC 3.1.3.1), lactate dehydrogenase (LDH, EC 1.1.1.27), and $\gamma$-hydroxybutyrate dehydrogenase (isoenzymes of LDH: LDH-1 and LDH-2). Total proteins and enzyme activity were measured using commercial kits (DIALAB, Austria; Randox Laboratories, UK). The results were registered photometrically using a biochemical analyzer RX Daytona (Randox Laboratories, UK).

Biochemical parameters obtained were processed by one-way ANOVA using SigmaStat software (Systat Software Inc., USA). The significance of differences was estimated using Tukey's test for normal distribution or Dunn's test for the absence of normal distribution, the accepted significance level was $\mathrm{p}<0.05$. Correlations were calculated using Spearman's rank correlation coefficient

Results. According to most researchers, the energy balance is the main factor determining the realization of reproductive potential in dairy cattle [22]. Earlier, we have obtained the data on the role of protein and carbohydrate metabolism in maintaining reproductive ability of cows during the critical physiological periods [12-15]. Therefore, the enzymes that regulate carbohydrate and protein, and energy metabolism in animals were subjected to the study, particularly ALT and AST the activity of which was related to the reproduction intensity in high yielding cows $[12,15]$. In addition, differences in GGT, CPK, ALP, and AST activity were found in meat and dairy goats with different number of kids per litter [11], which was also the basis for the study of these enzymes.

A comparison of biochemical parameters revealed differences in blood enzyme activity in Saanen goats in the course of a complete reproductive cycle (Table 1).

Activity of blood AST which catalyzes the reversible reaction of aspartate transition to oxaloacetate was found to be lower in the second half of gestation compared to pre-mating period or the first half of gestation $(\mathrm{p}<0.05)$. The activity of serum ALT involved in the mutual transformations of alanine and pyruvate increased by gestation months $1.5-2.5$ versus pre-mating period $(p<0.05)$, followed by a decrease by gestation months 3.5-4.0 ( $\mathrm{p}<0.001)$. In addition, there was a negative correlation between the activity of both enzymes and gestational age $(r=-0.690$ and $r=-0.634$ for AST and ALT, respectively, $\mathrm{p}<0.001)$. De Ritis ratio (AST/ALT) which characterizes the ratio of catabolic and anabolic processes in the body [23], was 2 times higher in the second half of gestation versus the first half $(\mathrm{p}<0.01)$ which was the result of a 2 -fold reduce in ALT activity. These findings indicate a simultaneous reduction in the intensity of tricarboxylic acid and glucose-alanine cycles with a shift of metabolic processes towards catabolism in maternal organism by the end of gestation. This conclusion is consistent with the data on total blood protein level which changed with the change in ALT activity unidirectionally, although the change was less significant and was negatively associated with the gestational age $(r=-0.444$, $\mathrm{p}<0.05)$. Earlier, in the investigation of blood protein and carbohydrate metabolism enzyme activity in Black-and-White heifers, we found a similar decrease in ALT and AST in gestation months 7-8, which is obviously due to the need to meet the increased fetal requirements in energy and proteins [15]. However, de Ritis ratio was decreased or remained unchanged in heifers (unlike goats) by the end of pregnancy, which is consistent with the data on their ana- 
bolic metabolism until the last 2-3 weeks of gestation [24].

1. Blood biochemical parameters in Saanen goats (Capra hircus) during the completed reproductive cycle $(X \pm \mathrm{SEM}, n=15$, Prinevskoe JSC stud farm, Vsevolzhsk region, Leningrad Province, 2010-2011)

\begin{tabular}{|c|c|c|c|}
\hline Parameter & Pre-mating period & 1-st half of gestation & 2-nd half of gestation \\
\hline$\overline{\mathrm{AST}}, \mathrm{U} / \mathrm{l}$ & $95.8 \pm 3.7^{\mathrm{a}}$ & $98.3 \pm 4.6^{\mathrm{a}}$ & $80.0 \pm 4.9^{\mathrm{b}}$ \\
\hline ALT, U/1 & $20.1 \pm 0.7 \mathrm{c}$ & $25.9 \pm 1.0^{\mathrm{d}}$ & $13.4 \pm 1.9^{\mathrm{e}}$ \\
\hline AST/ALT & $4.9 \pm 0.3$ & $3.8 \pm 0.2^{\mathrm{f}}$ & $7.5 \pm 1.2 \mathrm{~g}$ \\
\hline GGT, units/1 & $54.7 \pm 4.2$ & $57.5 \pm 4.6^{\mathrm{h}}$ & $43.2 \pm 2.9^{\mathrm{i}}$ \\
\hline CPK, U/1 & $202.0 \pm 15.0^{j}$ & $253.0 \pm 69.0^{j}$ & $131.0 \pm 22.0^{\mathrm{k}}$ \\
\hline ALP, units/1 & $43.6 \pm 2.3^{1}$ & $63.8 \pm 4.9^{\mathrm{m}}$ & $89.5 \pm 6.4^{\mathrm{n}}$ \\
\hline $\mathrm{LDH}, \mathrm{U} / 1$ & $724.0 \pm 28.0$ & $709.0 \pm 50.0$ & $754.0 \pm 40.0$ \\
\hline $\mathrm{LDH}-1+\mathrm{LDH}-2, \mathrm{U} / 1$ & $309.0 \pm 11.0$ & $321.0 \pm 21.0^{\circ}$ & $252.0 \pm 11.0^{\mathrm{p}}$ \\
\hline Total protein, g/L & $71.1 \pm 2.6$ & $77.8 \pm 2.0$ & $71.9 \pm 2.7$ \\
\hline \multicolumn{4}{|c|}{ 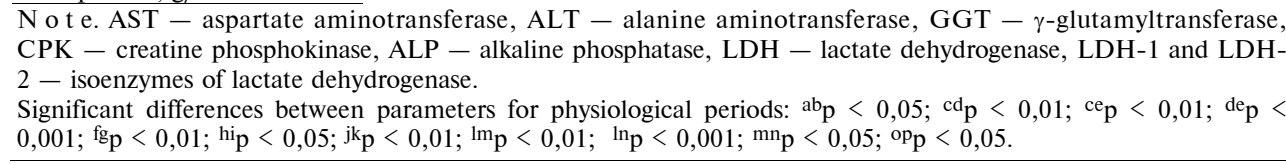 } \\
\hline
\end{tabular}

Blood GGT activity in the first half of gestation was not different from that in pre-mating period, but decreased sequentially by gestation months 3.5-4.0 ( $\mathrm{p}<0.05)$. In addition, it correlated with gestational age negatively $(r=-0.588, \mathrm{p}<0.01)$. One of GGT functions is known to be related to the regulation of amino acid transport into the cells via $\gamma$-glutamine cycle. Therefore, the reduced activity of this enzyme in the second half of gestation may indicate a decrease in the availability of amino acids in the mother's body both for protein synthesis and as glucogenic substrates.

The activity of CPK which catalyzes the reversible transfer of macroergic phosphates from ATP to creatine and from creatine phosphate to ADP decreased in goat blood $(\mathrm{p}<0.01)$ in the second half of gestation and was negatively related to the gestational age $(r=-0,574, \mathrm{p}<0.01)$. This change in CPK activity indicates a decrease in the intensity of energy metabolism by the end of pregnancy.

On the contrary, the activity of ALP which is involved in nonspecific dephosphorylation and phosphorus transport through cell membranes was increased by $1.5-2.5$ months of gestation $(p<0.05)$, and then continued to rise to 3.5-4.0 months $(\mathrm{p}<0.01)$. At the same time, we found a positive correlation between ALP activity and the gestational age $(r=0.456, \mathrm{p}<0.05)$. Increased ALP activity in goats during pregnancy was apparently due to one of its isozymes, the placental ALP [25]. We can not exclude a compensatory role of this increase in the total energy metabolism against a decrease in activity of tricarboxylic acid cycle, glucose-alanine cycle, etc. Indeed, no increases in blood AP activity are observed in Black-and-White heifers in which the anabolic character of metabolism is maintained in the late gestation [15].

Activity of blood glycolytic enzyme LDH which catalyzes the reversible conversion of lactate to pyruvate reaction did not differ in goats during the reproductive cycle. Lack of relevant changes for $\mathrm{LDH}$ in different gestation phases has also been noted earlier in heifers [15]. At the same time, the activity of LDH-1 and LDH-2 isozymes which support aerobic glycolysis, decreased in the second half of gestation $(\mathrm{p}<0.05)$. Data analysis revealed the presence of a significant negative correlation between the gestational age and the total activity of the two above LDH isoforms $(r=-0.546, \mathrm{p}<0.01)$. These isozymes that are present mainly in the heart muscle, erythrocytes, platelets, brain and kidney tissues, have a high affinity for lactic acid and convert it efficiently into pyruvate for subsequent inclusion in tricarboxylic acid cycle. A decrease in LDH-1 + LDH-2 activity indicates a reaction shift toward formation of lactate and, thus, a 
reduction in the Krebs cycle intensity, at least in cells of the above types, which agrees with the detected decrease in AST activity in the second half of gestation. In addition, these findings give reason to believe that the lactic acid excess in goats in this period is transported to the bloodstream of the fetus and can be used by the latter for the synthesis of non-essential amino acids and lipids and as an energy substrate (after oxidation to pyruvate). The same is known to take place in sheep [26]. This assumption is also evidenced by the data on the increased fetal lactate uptake rate in horses by the end of pregnancy [27].

Thus, activity of some enzymes related to protein-carbohydrate and energy exchange decreased in Saanen goats by gestation month 4. Decreased activity of certain blood enzymes was also observed in the second trimester of pregnancy in women [28] and in the third trimester of gestation in heifers [15]. This suggests that at certain stages of pregnancy (specific of mammal species), maternal organisms start to function in the mode of saving own resources to maintain increased fetal requirements

When comparing blood enzyme activity in pre-mating period, differences in ALT and GGT activity were found in goats with different capacity to maintain pregnancy (Table 2). Blood ALT and GGT activity in the animals with interrupted reproductive cycle was considerably lower compared to the goats with retained pregnancy $(\mathrm{p}<0.05)$. At the same time, there were no significant differences in blood biochemical parameters in the animals of compared groups in the first half of gestation (see Table 2). The increase in blood ALT activity by gestation months 2-3 had different intensities in the two groups. It increased 1.3 times $(\mathrm{p}<0.001)$ in the goats with completed reproductive cycle and 1.8 times in the goats with interrupted cycle. At the same time, blood GGT activity in the first half of gestation did not differ from that in premating period in both goat groups.

2. Blood biochemical parameters in Saanen goats (Capra hircus) in pre-mating period and in the first half of gestation in further completed and interrupted reproductive cycles $(X \pm \mathrm{SEM}$, Prinevskoe JSC stud farm, Vsevolzhsk district, Leningrad region, 2010-2011)

\begin{tabular}{|c|c|c|}
\hline Parameter & Group I $(n=15)$ & Group II $(n=6)$ \\
\hline \multicolumn{3}{|c|}{ Pre-mating period } \\
\hline AST, U/1 & \multirow{2}{*}{$\begin{array}{l}95.8 \pm 3.7 \\
20.1 \pm 0.7\end{array}$} & $89.2 \pm 8.0$ \\
\hline $\mathrm{ALT}, \mathrm{U} / 1$ & & $14.4 \pm 2.9^{*}$ \\
\hline AST/ALT & $4.9 \pm 0.3$ & $11.3 \pm 5.7$ \\
\hline GGT, U/1 & $54.7 \pm 4.2$ & $43.8 \pm 2.4^{*}$ \\
\hline CPK, U/1 & $202.0 \pm 15.0$ & $172.0 \pm 8.0$ \\
\hline ALP, U/1 & $43.6 \pm 2.3$ & $38.1 \pm 5.1$ \\
\hline $\mathrm{LDH}, \mathrm{U} / 1$ & $724.0 \pm 28.0$ & $679.0 \pm 60.0$ \\
\hline \multirow[t]{2}{*}{$\mathrm{LDH}-1+\mathrm{LDH}-2, \mathrm{U} / 1$} & $309.0 \pm 11.0$ & $307.0 \pm 21.0$ \\
\hline & \multicolumn{2}{|l|}{ First half of gestation } \\
\hline AST, U/1 & $98.3 \pm 4.6$ & $95.7 \pm 2.9$ \\
\hline $\mathrm{ALT}, \mathrm{U} / 1$ & $25.9 \pm 1.0$ & $25.9 \pm 1.6$ \\
\hline AST/ALT & $3.8 \pm 0.2$ & $3.8 \pm 0.3$ \\
\hline GGT, U/1 & $57.5 \pm 4.6$ & $48.0 \pm 3.7$ \\
\hline CPK, U/1 & $253.0 \pm 69.0$ & $216.0 \pm 17.0$ \\
\hline ALP, U/1 & $63.8 \pm 4.9$ & $73.4 \pm 8.7$ \\
\hline $\mathrm{LDH}, \mathrm{U} / 1$ & $709.0 \pm 50.0$ & $627.0 \pm 73.0$ \\
\hline $\mathrm{LDH}-1+\mathrm{LDH}-2, \mathrm{U} / 1$ & $321.0 \pm 21.0$ & $283.0 \pm 18.0$ \\
\hline Total protein, $\mathrm{g} / \mathrm{l}$ & $77.8 \pm 2.0$ & $80.1 \pm 3.4$ \\
\hline \multicolumn{3}{|c|}{$\begin{array}{l}\text { N o t e. AST - aspartate aminotransferase, ALT - alanine aminotransferase, GGT }-\gamma \text {-glutamyltransferase, } \\
\text { CPK - creatine phosphokinase, ALP }- \text { alkaline phosphatase, LDH }- \text { lactate dehydrogenase, LDH- } 1 \text { and LDH- } \\
2-\text { isoenzymes of lactate dehydrogenase; group I }- \text { animals with completed reproductive cycle (birth of viable } \\
\text { offspring), group II }- \text { animals with interrupted reproductive cycle (abortions in the second half of gestation). } \\
* \text { Intergroup differences are significant at } \mathrm{p}<0.05 \text {. }\end{array}$} \\
\hline
\end{tabular}

Thus, the enzyme status of goats with interrupted reproductive cycle (abortion in the second half of gestation) is characterized by reduced ALT and GGT activity in pre-mating period. This demonstrates the reduced intensity of 
glucose-alanine and $\gamma$-glutamine cycles and hence the decreased gluconeogenesis rate in the formation of mature oocytes in the ovary. To date, adequate glucose provision for maturing mammalian oocytes has been found to be crucial for their capacity of further embryonic development [29, 30]. In this, glucose entry into the blood in ruminants is mainly provided by gluconeogenesis. Earlier, we have demonstrated that decreased blood ALT activity in high yielding cows at the end of milking period (before the onset of pregnancy) is associated with the increased duration of service period $[12,13]$ which is known to be largely depend on embryonic and early fetal mortality [31]. Data obtained in dairy goats point to a possible link between the intensity of gluconeogenesis in premating period and oocyte quality characteristics that determine fetal capacity to survive in the later gestation period.

Is necessary to note that female fertility may be affected not only by metabolic, but also by immune, endocrine, oxidative and other factors that were beyond the scope of this study.

Thus, the comparative study of metabolic blood enzymes in the high productive Saanen goats in pre-mating period and during gestation suggest a reduction in the intensity of some metabolic processes in the animals by the fourth month of pregnancy to maintain the increased fetal requirements in energy and metabolic substrates. Our findings also demonstrate that the activity of enzymes which regulate relationship of protein metabolism to carbohydrate metabolism in goat during the pre-mating period may be related to the subsequent fetus maintenance.

\section{R E F E R E N C ES}

1. N ov opash in a S.I., S a n i kov M.Yu. Ovtsy, kozy, sherstyanoe delo, 2013, 2: 61-65 (in Russ.).

2. Shuvarikov A.S., Aleshina M.N., Pastukh O.N. Ovtsy, kozy, sherstyanoe delo, 2013, 1: 30-32 (in Russ.).

3. L y a g i n F.F. Zootekhniya, 2003, 5: 25-27 (in Russ.).

4. Plemyashov K.V., Andreev G.M., Dmitrieva T., Stakheeva M. Mezhdunarodnyi vestnik veterinarii, 2008, 3: 6-8.

5. Dobson H., Smith R.F., Royal M.D., Knight Ch., Sheldon I. The high producing dairy cow and its reproductive performance. Reprod. Domest. Anim., 2007, 42(Suppl. 2): 17-23 (doi: 10.1111/j.1439-0531.2007.00906.x).

6. Lebedev V.A., Lebedeva I.Yu., Kuz'mina T.I., Shapiev I.Sh. Rol'metabolicheskikh gormonov $\mathrm{v}$ regulyatsii funktsii yaichnikov u korov [Role of metabolic hormones in the regulation of ovarian function in cattle (review)]. Sel'skokhozyaistvennaya biologiya [Agricultural Biology], 2005, 2: 14-22 (in Russ.).

7. Kh a n J.R., L u d r i R.S. Changes in blood glucose, plasma non-etherified fatty acids and insulin in pregnant and non-pregnant goats. Trop. Anim. Health Prod., 2002, 34(1): 81-90.

8. I s mail Z.A., A l-M a ja 1 i A.M., A mi re h F., Al-R aw a shdeh O.F. Metabolic profiles in goat does in late pregnancy with and without subclinical pregnancy toxemia. Vet. Clin. Pathol., 2008, 37(4): 434-437 (doi: 10.1111/j.1939-165X.2008.00076.x).

9. M a g istrelli D., R os i F. Trend analysis of plasma insulin level around parturition in relation to parity in Saanen goats. J. Anim. Sci., 2014, 92(6): 2440-2446 (doi: 10.2527/jas.2013-6993).

10. Radin L., Ši m praga M., Vince S., Kostelić A., Milinković-Tur S. Metabolic and oxidative status of Saanen goats of different parity during the peripartum period. $J$. Dairy Res., 2015, 82(4): 426-433 (doi: 10.1017/S0022029915000552).

11. Djuricic D., Dobranic T., Grizelj J., Gracner D., Harapin I., Stanin D., Folnozic I., Getz I., Cvitkovic D., S a mardzija M. Concentrations of total proteins and albumins, and AST, AP, CK and GGT activities in the blood serum Boer and Saanen goats during puerperium. Reprod. Domest. Anim., 2011, 46(4): 674-677 (doi: 10.1111/j.14390531.2010.01726.x).

12. Le ibova V.B., Shapiev I.Sh., Le be deva I.Yu. Metabolicheskoe sostoyanie v kontse perioda razdoya u vysokoproduktivnykh molochnykh korov s raznoi vosproizvoditel'noi sposobnost'yu [Metabolic state at the end of early lactation in high-producing dairy cows with different reproductive abilities]. Sel'skokhozyaistvennaya biologiya [Agricultural Biology], 2011, 6: 103- 
109 (in Russ.).

13. Le ib ova V.B., Sha pi e v I.Sh., L e be d e va I.Yu.. Problemy biologii produktivnykh zhivotnykh, 2011, 4(spets. vypusk): 70-72 (in Russ.).

14. Le ib ov a V.B., L e b e d e va I.Yu. Dostizheniya nauki i tekhniki APK, 2011, 10: $45-47$ (in Russ.).

15. L e b e d e va I.Yu., L e i b ov a V.B., E rnst L.K. Doklady RASKhN, 2012, 3: 52-54 (in Russ.).

16. S k l y a r o v P.N. Materialy XVI Mezhdunarodnoi nauchno-prakticheskoi konferentsii "Aktual'nye problemy intensivnogo razvitiya zhivotnovodstva» [Proc. Int. Conf. «Actual aspects of intensive animal farming» (in Russ.)]. Gorki, Respublika Belarus', 2013: 205-212.

17. Van den Brom R., Lievaart-Peterson K., Luttikholt S., Peperkamp K., Wouda W., Velle ma P. Abortion in small ruminants in the Netherlands between 2006 and 2011. Tijdschr. Diergeneeskd., 2012, 137(7): 450-457.

18. S z e redi L., Já nos i S., Te nk M., T e kes L., B ozs y M., De i m Z., Molnár T. Epidemiological and pathological study on the causes of abortion in sheep and goats in Hungary (1998-2005). Acta Vet. Hung., 2006, 54(4): 503-515.

19. M o e 11 e r R.B. Causes of caprine abortion: diagnostic assessment of 211 cases (1991-1998). J. Vet. Diagn. Invest., 2001, 13(3): 265-270 (doi: 10.1177/104063870101300317).

20. Nezhdanov A.G., Retski M.I., Ale kh i n Yu.N., S a fonov V.A., Shu shlebin V.I., Papin N.E., B rekhov T.P., Shishkina E.V. Kliniko-gematologicheskii i biokhimicheskii status korov pri gestoze [Clinico-hematologic and biochemical status of cows at gestosis]. Sel'skokhozyaistvennaya biologiya [Agricultural Biology], 2010, 4: 118-123 (in Russ.).

21. M i s a ilov V.D., N e zhd a nov A.G., Kot s a rev V.N., Ko c hura M.N., M i k h a 1 e v V.I., S k r y l' n i k o v O.N., S u 1 e i m a n o v S.M., Z o 1 o t a r e v A.I. Rossiiskii veterinarnyi zhurnal, 2007(spets. vypusk, May): 13 (in Russ.).

22. Chagas L.M., B a s s J.J., B la che D., B u rke C.R., K a y J.K., L ind s a y D.R., Luc y M.C., M a rtin G.B., M e i e r S., Rhodes F.M., Roche J.R., That c h e $\mathrm{r}$ W.W., W e b b R. Invited review: New perspectives on the roles of nutrition and metabolic priorities in the subfertility of high-producing dairy cows. J. Dairy Sci., 2007, 90(9): 4022-4032 (doi: 10.3168/jds.2006-852).

23. Roslyi I.M., Abramov S.V., Pokrovski i V.I. Vestnik RAMN, 2002, 8: 3-9 (in Russ.).

24. Z u lu V.C., S a w a muka i Y., N a k a d a K., K id a K., Mori y o shi M. Relationship among insulin-like growth factor-I, blood metabolites and postpartum ovarian function in dairy cows. J. Vet. Med. Sci., 2002, 64(10): 879-885 (doi: 10.1292/jvms.64.879).

25. M i y a z a w a K., T o m o d a I. Immunological investigation of intestinal, liver, kidney, bone, placental and serum alkaline phosphatase in cattle. Nihon Juigaku Zasshi, 1989, 51(2): 309-314.

26. C a rte r B.S., M o o res R.R. Jr., T e ng C., M e s c hi a G., B a t t a g li a F.C. Main routes of plasma lactate carbon disposal in the midgestation fetal lamb. Biol. Neonate, 1995, 67(4): 295-300 (doi: 10.1159/000244177).

27. F o w d e n A.L., T a y 1 o r P.M., Wh i t e K.L., F o r h e a d A.J. Ontogenic and nutritionally induced changes in fetal metabolism in the horse. J. Physiol., 2000, 528(1): 209-219 (doi: 10.1111/j.1469-7793.2000.00209.x).

28. Roslyi I.M., Abramov S.V. Voprosy ginekologii, akusherstva i perinatologii, 2005, 4(2): 7-13 (in Russ.).

29. L e r o y J.L., V a n S o o m A., O p s o m e r G., B o ls P.E. The consequences of metabolic changes in high-yielding dairy cows on oocyte and embryo quality. Animal, 2008, 2(8): 1120-1127 (doi: 10.1017/S1751731108002383).

30. Sutton-M c D ow a 11 M.L., Gilch rist R.B., Thom p s o n J.G. The pivotal role of glucose metabolism in determining oocyte developmental competence. Reproduction, 2010, 139(4): 685-695 (doi: 10.1530/REP-09-0345).

31. D i s k i n M.G., M o r r i s D.G. Embryonic and early foetal losses in cattle and other ruminants. Reprod. Domest. Anim., 2008, 43(Suppl. 2): 260-267 (doi: 10.1111/j.1439-0531.2008.01171.x). 